\title{
تأثير استخدام بعض الأساليب التسويقية على مدارس كرة القدم بدولة الكويت
}

أ. أ.داعادل محمد عبدالمنعم مكي

أحمد محمد عبد الله الاليم عدم مديم

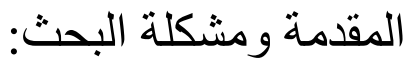

مع تطور الاستثمار واتساع رفعته أصبحت العلاقة بين السياحة والاقتصاد

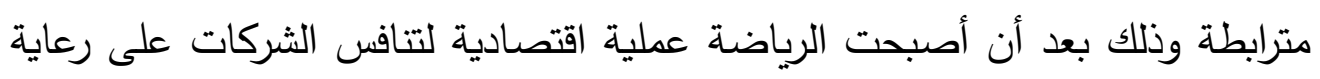
الأحداث الرياضية حيث يلعب الرعاة دوراً هاماً فى نجاح البطولات الرياضية الرئية.

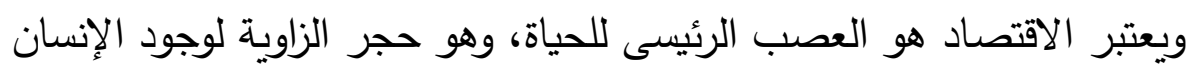

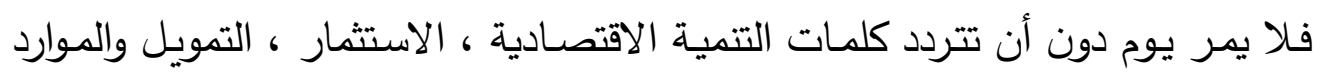

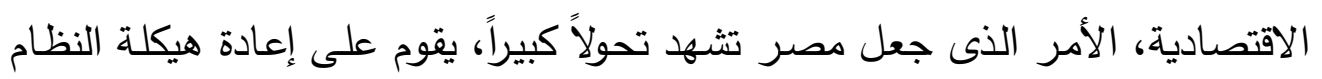

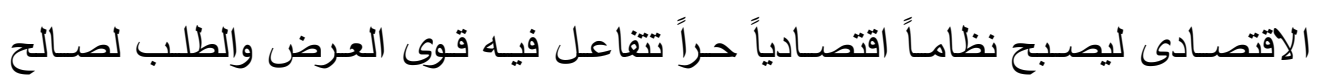
المستهلك، باعتباره سيد السوق فى أي نظام تنافسى. (8: 1: 1) ويذكر حامد عبد المجيد (2000) أنه لكى تتجح السياسة المالية فى تحقيق أهدافها فلابد من استخدام الأساليب العلمية السليمة لتحليل النثاط الاقتصادى بدقة ،

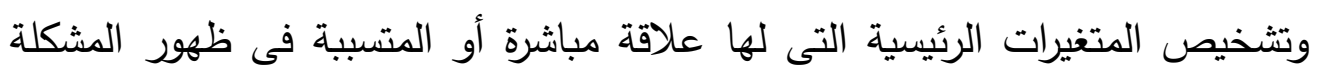

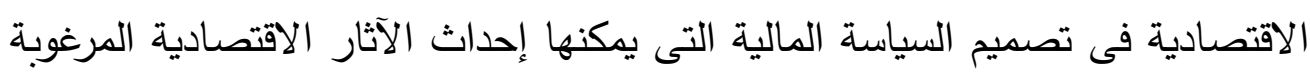
على هذه المتغيرات مباشرة دون غيرها (2: 54 )

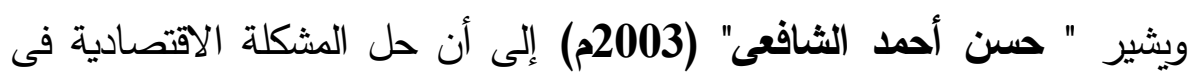

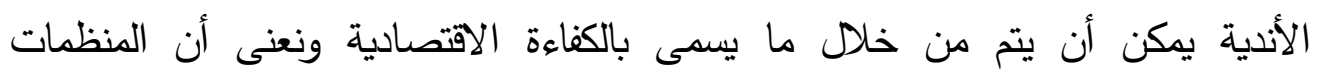

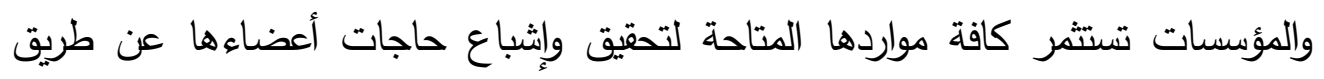

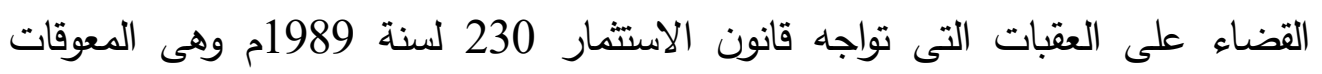

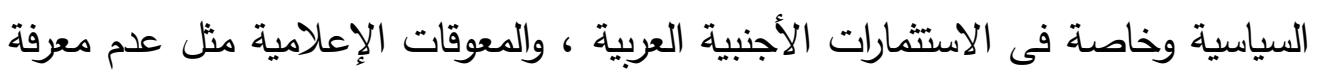

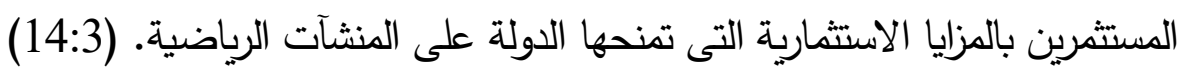


وقد عرف " كوتلر وارمسترونج Kotler \& Armstrong (2001م) التسويق

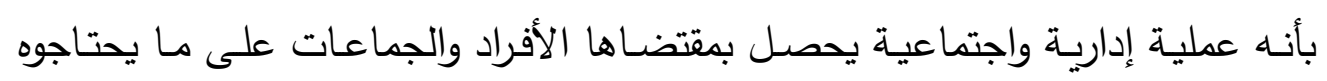
ويريدونه من خلال خلق وتقديم وتبادل منتجات لها قيمة لاى الآخرون. (12 :

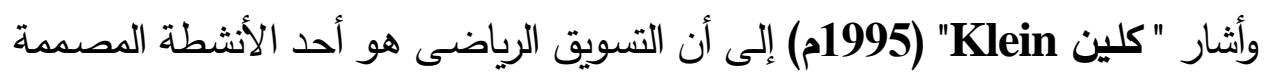

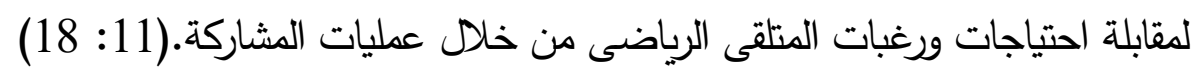

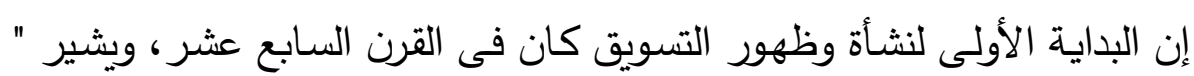

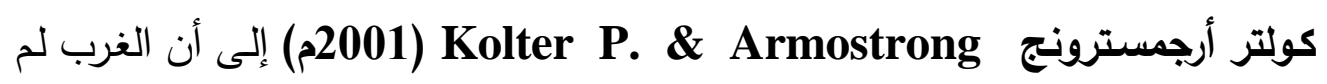
يعرف شيئا عن التسويق إلا فى منتصف القرن التاسع عشر على يد شركة هارفيستر العالمية، أما منظمات الأعمال فقد ظهر أول " قسم للتسويق" "وبحوث التسويق" في أوائل

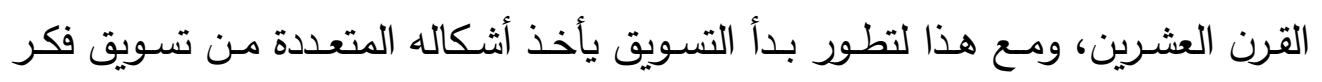

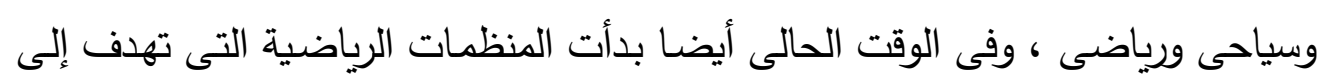

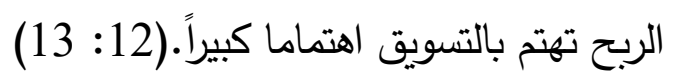

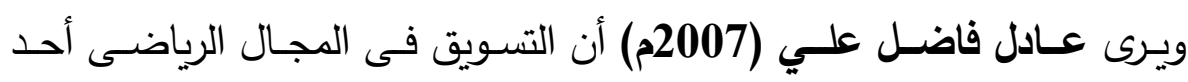

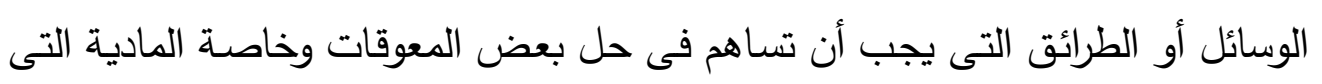

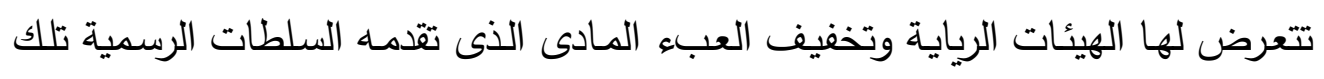
الهيئات، وإذا أمكن إدخال التسويق الرياضى للهيئات الرياضية و استخدام إمكانياتها فإنه الرئه

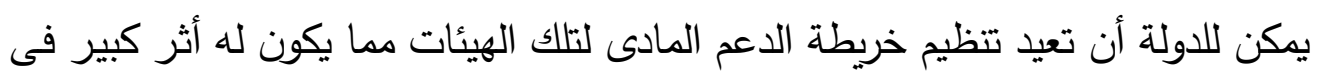
إعادة التوازنات بين تلك الهيئات يحقق ذلك المساهمة في تحقيق تلك الهيئات لكادئ لأهدافها

المرجوة.4) (2:)

فالتمويل فى المجال الرياضى هو مجموع الموارد المالية والعينية التى يحصل عليها

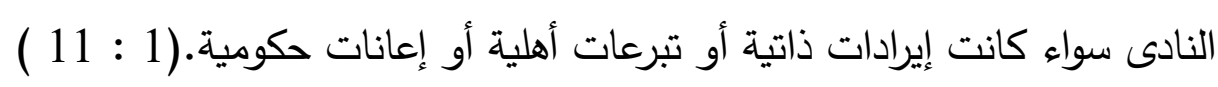

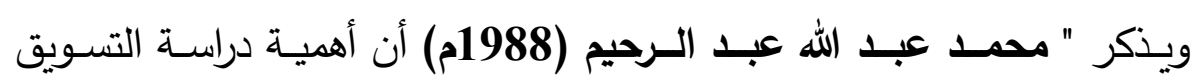

الرياضى تتحصر فى النقاط التالية: 1- يشجع التسويق فى الابتكار والنمو.

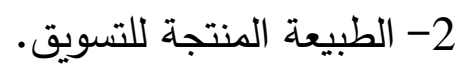


3- ارتفاع تكلفة التسويق.

$$
\text { 4- ضرورة تقييم أنشطة التسويق.(8: 40-43) }
$$

ومن خلال الرجوع إلى المسح المرجعى للمراجع والبحوث العلمية التى ارتبطت بمجال التسويق فى المجال الرياضى - وفى حدود علم الباحث - لم يتم التطرق إلى لـى

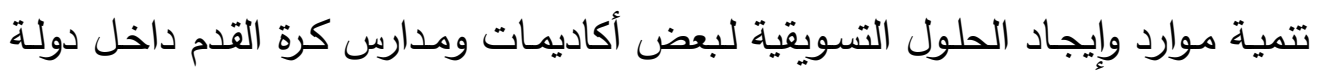
الكويت من خلال تسويق أنشطتها المختلفة بالرغم من وجود عجز فى مواردها وهذا ما لـا

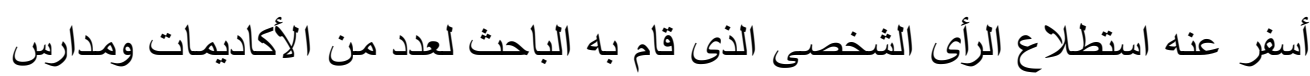

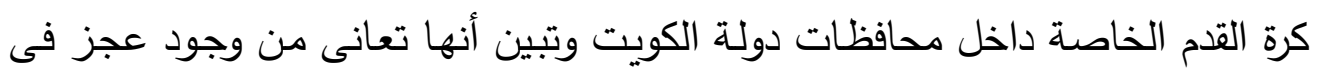

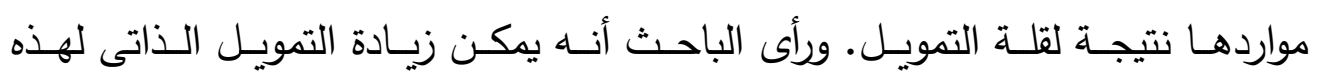
الأكاديميات من خلال تسويق أنشطتها المختلفة فى تتمية موارد هذه الأكاديميات. من هنا جاءت فكرة البحث الحالى والتى كانت بمثابة محاولة للبحث والدراسة عن هن مدى استحداث أساليب تسويقية لتسويق الأكاديميات ومدارس كرة القدم بدولة الكويت.

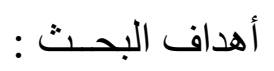
يهدف البحث التعرف على الأسـاليب التسويقية لبعض الأكاديميات ومدارس كرة القدم بدولة الكويت من خلال : أ - التسويق الرياضى. ب ب - التسويق الإنتاجى. ج - التسويق الخدمى..

$$
\text { تساؤلات البحــث: }
$$

1- يمكن الاستفادة من الأساليب التسويقية المختلفة لبعض الأكاديميات ومدارس

كرة القدم بدولة الكويت من خلال:

$$
\begin{aligned}
& \text { أ - التسويق الرياضى. } \\
& \text { ب - التسويق الإنتاجى. } \\
& \text { ج - التسويق الخدمى. } \\
& \text { مصطلحات البحــــث: } \\
& \text { التسويق Marketing : }
\end{aligned}
$$


يعرفه كمال درويش ومحمد صبحى حسانين (2004م) بأنه العملية الخاصة

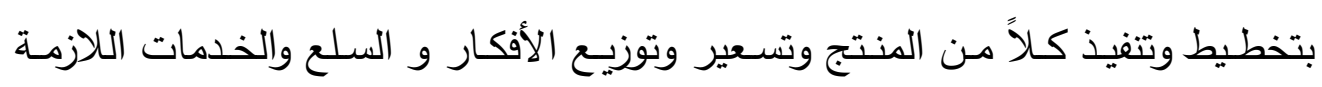

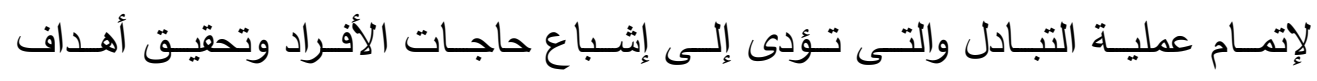
المنظمات.(6: 20) :Sport Marketing التسويق الرياضى :

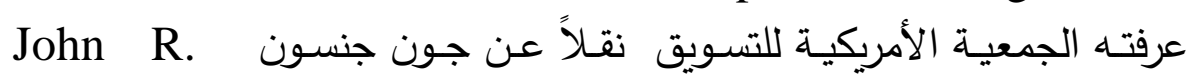
Johnson والخدمات من المنتج إلى المستهلك أو المستخدم. (10:

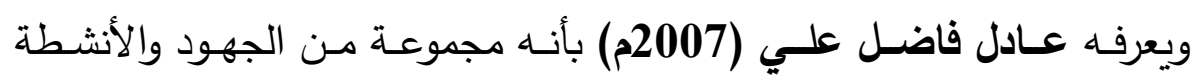

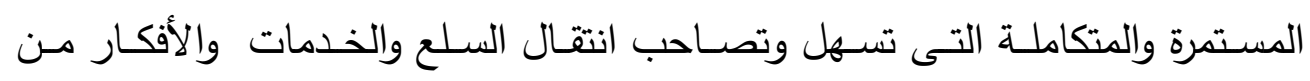

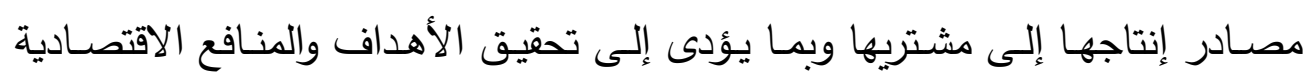
والاجتماعية للمستهلك والمنتج والمجتمع. (4 : 1 (1) الدر اسات السابقة:

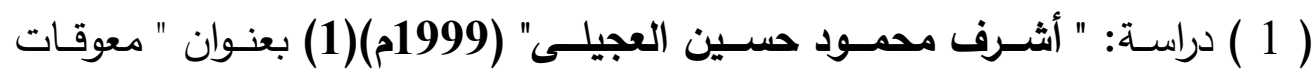

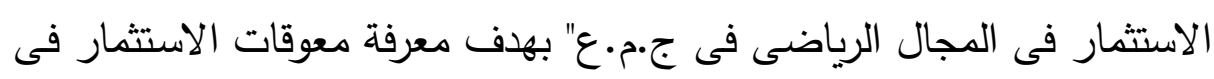

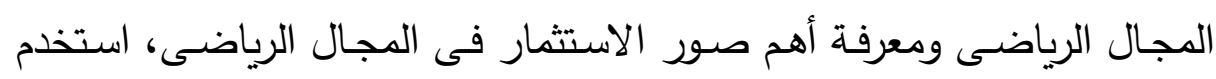

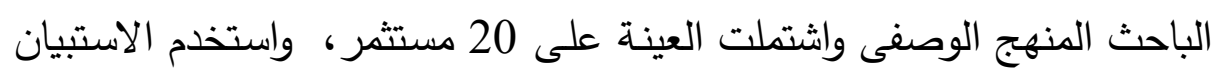

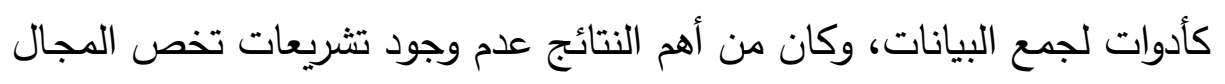

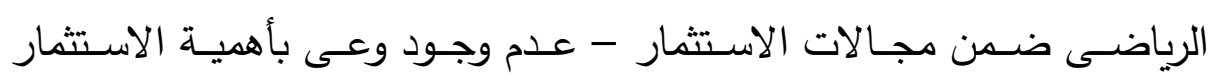

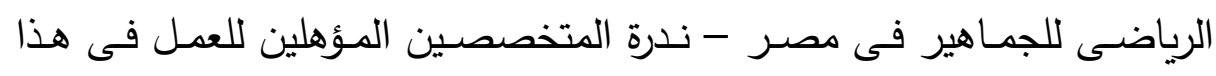

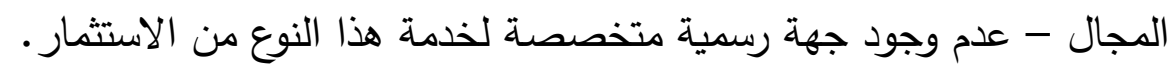

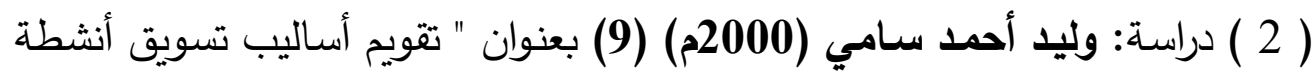

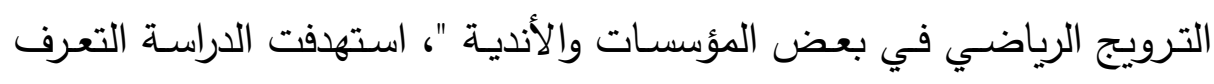

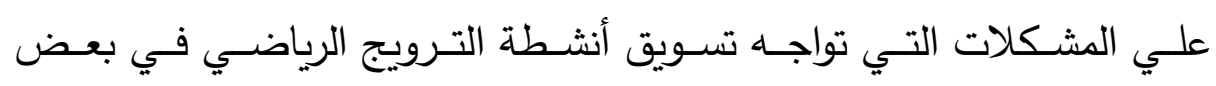


المؤسسات والأندية من وجهة نظر المستفيدين والمسئولين وكذلك تحديد أساليب

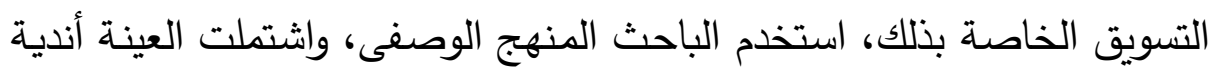

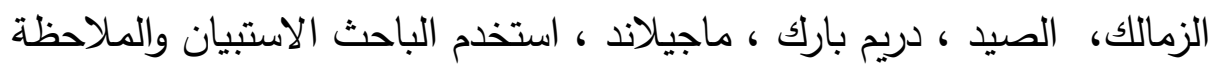

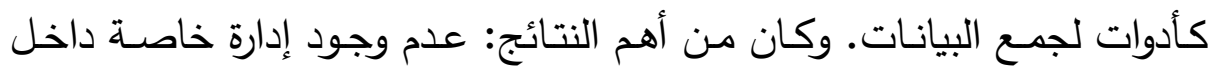

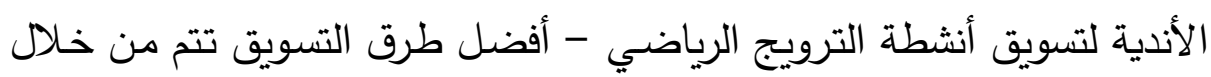
التلفزيون الإذاعة , الإنترنت ، عمل دعاية بالملاعب والصالات الرياضية . ( 3 ) دراسـة: عطيـه ســـ علـي الثــبراخيتي (2006 م)(5) بعنـوان " اسـتثمار الأنديـة

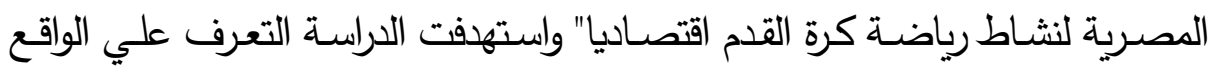

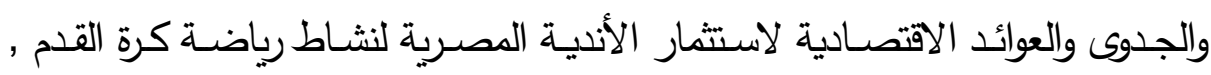
ونلك خلال الأهداف الفرعية التالية :- الواقع الاقتصادي لنشاط رياضـة كرة القدم -

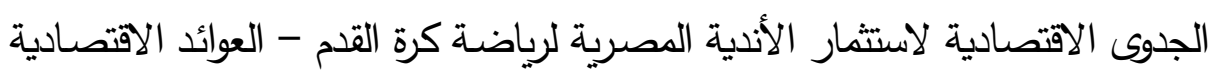

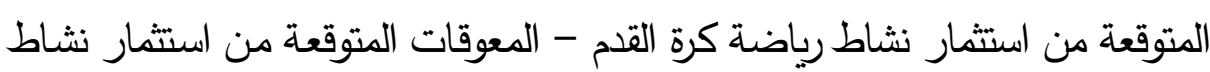
رياضـة كرة القدم، استخدم الباحث المنهج ألوصفي بأسلوب دراسـة الحالـة الملائمـة لطبيعة البحث، واشتملت العينة على عدد 225 فرد من مجتمع أندية الدوري الممتاز وبعض الخبراء والإعلاميين والمتخصصين، كما استخدم الباحث المقابلة الثخصية الاستبيان. وكان من أهم النتائج: الاتجاه نحو استثمار الأندية المصرية لنشاط كرة

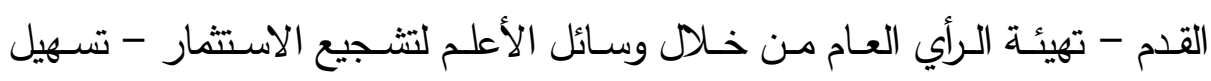

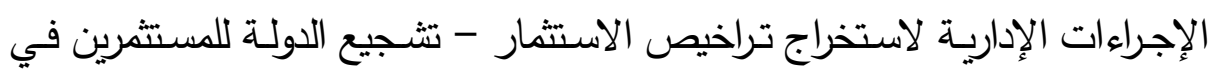

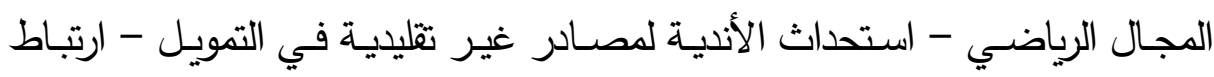

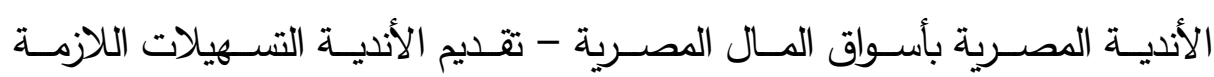

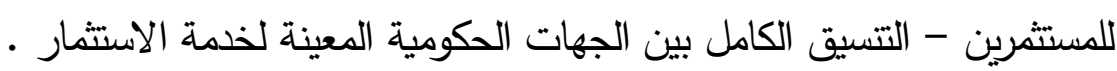


استخدم الباحث المنهج الوصفي بالأسلوب المسحي لمناسبته لطبيعة هذا

$$
\text { أولاً: منهـر اءات البحـث : }
$$

$$
\text { ثانياً: عينـة البحـث : }
$$

تم اختيار عينة البحث بالطريقة العمدية من أكاديميات ومدارس كرة القدم ببعض محافظات دولة الكويت متمثلة فى رؤساء مجالس إدارات الأكاديميات ومدارس كرة القدم وعددهم (6) ، بالإضافة إلى الهيكل التتظيمي بالأكاديمات والمدارس وعددهم (144) وبعض من أفراد الجمعيات العمومية (70) فرداً، تم سحب عدد (40) فرداً للدراسة الاستطلاعية وبذلك تصبح عينة البحث الأساسية عددها (180) فرداً. والجدول

\begin{tabular}{|c|c|c|c|c|c|c|}
\hline \multicolumn{2}{|c|}{ عينة استطلاعية } & \multicolumn{2}{|c|}{ عينة أساسية } & \multirow[t]{2}{*}{ العدد } & \multirow[t]{2}{*}{ تصنيف عينة البحث } & \multirow[t]{2}{*}{ p } \\
\hline نسبة & عدد & نسبة & عدد & & & \\
\hline$\% 0.45$ & 1 & $\% 2.27$ & 5 & 6 & رؤس رؤســاء مجـــالس الإدارات الأكاديميـــات & 1 \\
\hline$\% 11.36$ & 25 & $\% 54.09$ & 119 & 144 & القيكل التظيمي بأكاديميات ومدارس كرة & 2 \\
\hline$\% 6.36$ & 14 & $\% 25.45$ & 56 & 70 & أفراد الجمعيات العمومية & 3 \\
\hline$\% 18.18$ & 40 & $\% 81.81$ & 180 & 220 & المجموع & \\
\hline
\end{tabular}
التالي يوضح ذلك.

\section{جدول رقم ( 1 )}

\section{توصيف عينة البحث}

$$
\text { ثنالثاً: أدوات جمع البيانات : المجاع }
$$

- - المقابلة الثخصية: وذلك للاستفادة المباشرة من السادة الخبراء والتوصل لأكبر آراء

$$
\text { ومقترحات يقومون بتقديمها للباحث }
$$

- - المسـح المرجعي: وذلك بـالاطلاع على بعض الكتب والدوريات العلميـة التى تتاولت موضوع البحث. 
- استطلاع الخبراء: وذلك بعرض ما تم الوصول إليه من المسح المرجعى لعرضـه على السادة الخبراء لإقراره ومدى ملائمته للبحث الحالى أم لا. لأل

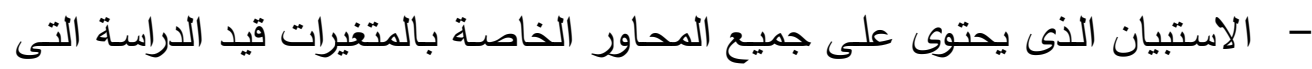

$$
\begin{aligned}
& \text { قام الباحث ببنائها لجمع بيانات بحثه. } \\
& \text { خطو ات بناء الاستبيان : } \\
& \text { 1- استطلاع أر اء الخبر اء :- }
\end{aligned}
$$

مـن خـلال المسـح المرجعي للدراسـات والمراجـع العربيـة والأجنبيـة المرتبطــة بمتغيرات البحث وقد تم التوصل إلى النسبة المئوية لآراء الخبراء فى محاور استمارة الاستبيان (قيد البحث).

\begin{tabular}{|c|c|c|}
\hline النسبة المئوية & 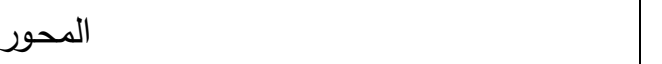 & s \\
\hline$\% 100$ & الأهداف العامة لأكاديميات ومدارس كرة القدم. & 1 \\
\hline$\% 100$ & | الخدمات التى تقدمها الأكاديميات للمشتركين. & 2 \\
\hline$\% 100$ & | إمكانات الأكاديمية المادية والبشرية. & 3 \\
\hline$\% 100$ & | مصادر تمويل الأكاديمية. & 4 \\
\hline$\% 100$ & | الأساليب التسويقية. & 5 \\
\hline
\end{tabular}

\section{جدول ( 2 )}

النسبة المئوية وفقا لآراء الخبراء للاستبيان

يتضـح من جدول (2) أن النسبة المئويـة لآراء السـادة الخبراء قد حققت نسبة

قدرها 100\% وقد أكدت على قبول جميع محاول الاستبيان. رابعاً: الدر اسـة الاستطلاعيـة:

قام الباحث بإجراء الدراسة الاستطلاعية خلاصل الفترة من 2019/1/15م إلى

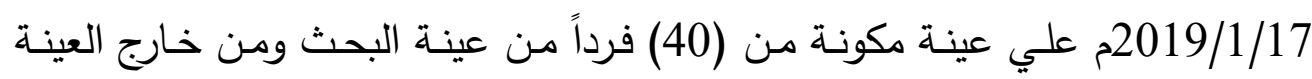
الأساسية (عند الدراسة الاستطلاعية) وذلك بهدف. 1. التعرف علي ملائمة العبارات لأفراد عينة الدراسة الاستطلاعية.

$$
\begin{aligned}
& \text { 2. تحديد زمن تطبيق الاستبيان وذلك بحساب :- } \\
& \text { (زمن أسرع مختبر + زمن أخر مختبر) }
\end{aligned}
$$


3. حساب المعاملات العلمية بالاستبيان.

المعاملات العلمية للاستمارة : 1 - صدق الاتساق الداخلى للاستبيان

قام الباحث بحساب الصدق على أفراد العينة الاستطلاعية الذى يبلغ عددها 40 فرداً عن طريق صدق الاتساق الداخلى، وذلك بحساب قيمة معامل الارتباط بين درجة كل عبارة على حدة بكل بعد والدرجة الكلية لهذا البعد مع الاستبيان ككل، كما

$$
\text { هو موضح بالجدولين ( } 4 \text { ، } 5 \text { ). }
$$

\section{جدول ( 3 )}

معامل الارتباط على صدق الاتساق الداخلي لعبارات محاور

$$
\text { الاستبيان }
$$

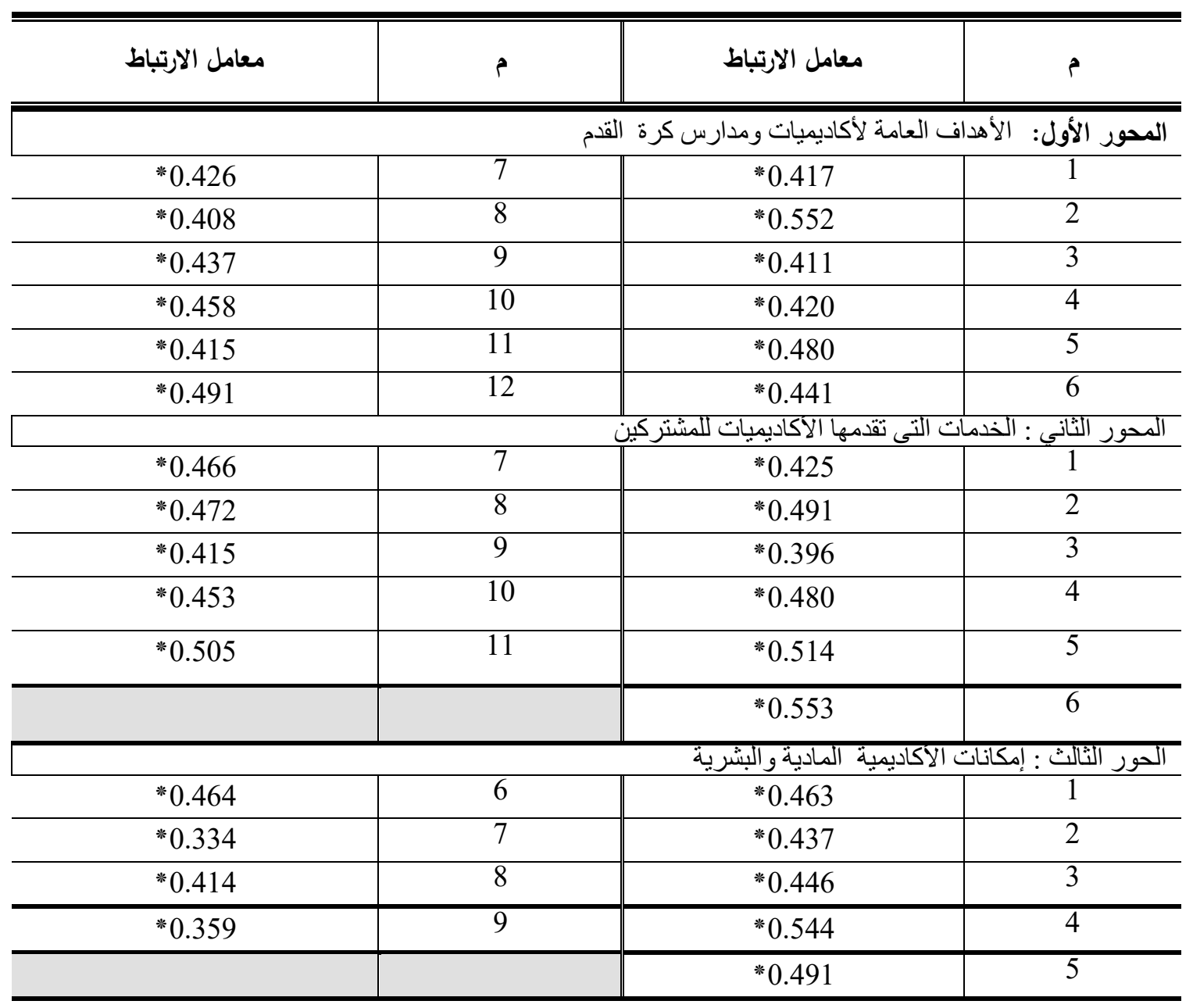




\section{تابع جدول ( 3 )}

معامل الارتباط على صدق الاتساق الداخلي لعبارات محاور الاستبيان

\begin{tabular}{|c|c|c|c|}
\hline معامل الارتباط & 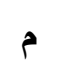 & معامل الارتباط & b \\
\hline \multicolumn{4}{|c|}{ المحور الرابع: مصادر تمويل الاكاديمية } \\
\hline *0.436 & 6 & *0.534 & 1 \\
\hline$* 0.511$ & 7 & $* 0.421$ & 2 \\
\hline$* 0.461$ & 8 & $* 0.437$ & 3 \\
\hline$* 0.586$ & 9 & $* 0.469$ & 4 \\
\hline & & $* 0.452$ & 5 \\
\hline \multicolumn{4}{|c|}{ المحور الخامس: الاساليب التسويقية: } \\
\hline *0.342 & 14 & $* 0.396$ & 1 \\
\hline$* 0.423$ & 15 & $* 0.481$ & 2 \\
\hline *0.491 & 16 & $* 0.366$ & 3 \\
\hline$* 0.435$ & 17 & $* 0.459$ & 4 \\
\hline$* 0.449$ & 18 & *0.476 & 5 \\
\hline$* 0.477$ & 19 & $* 0.499$ & 6 \\
\hline$* 0.474$ & 20 & $* 0.483$ & 7 \\
\hline *0.405 & 21 & *0.462 & 8 \\
\hline *0.473 & 22 & $* 0.567$ & 9 \\
\hline$* 0.581$ & 23 & $* 0.448$ & 10 \\
\hline *0.509 & 24 & $* 0.518$ & 11 \\
\hline \multirow[t]{2}{*}{ *0.573 } & 25 & $* 0.517$ & 12 \\
\hline & & *0.487 & 13 \\
\hline
\end{tabular}

يتضح من جدول ( 3 ) أن معاملات الارتباط بين كل عبارة والدرجة الكلية

للمحور دالة إحصائيا عند مستوى 0.05، مما يدل على صدق الاستبيان فيما وضـع من أجله. 
جدول ( 4 ( )

معامل الارتباط بين المحاور والارجة الكلية للاستبيان

\begin{tabular}{|c|c|c|}
\hline معامل الارتباط & 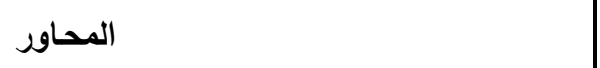 & b \\
\hline *0.704 & |الأهداف العامة لأكاديميات ومدارس كرة القدم & 1 \\
\hline *0.613 & |الخدمات التى تقدمها الأكاديميات للمشتركين & 2 \\
\hline$* 0.542$ & إمكانات الأكاديمية المادية والبشرية & 3 \\
\hline *0.597 & مصادر تمويل الأكاديمية & 4 \\
\hline *0.636 & |الأساليب التسويقية & 5 \\
\hline
\end{tabular}

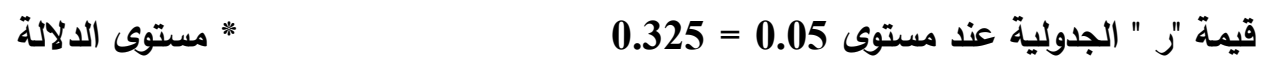

يتضـح مـن جدول ( 4 ) أن معـاملات الارتبـاط بين كل محور والدرجـة الكليـة

للمحاور دالة إحصائيا عند مستوى 0.05، مما يدل على صدق الاستبيان فيما وضع من

$$
\text { أجله. }
$$

2 - حساب معامل ثبات الاستبيان

تم حساب معامل ثبات الاستبيان على أفراد العينة الاستطلاعية وقوامها (40)

فرداً وذلك باستخدام تطبيق الاختبار وإعادة تطبيقه Test-Retest والجدول التالى (5) يوضح ذلك. 
جدول ( 5 )

معامل الثبات لاستمارة الاستبيان

\begin{tabular}{c|c|c|c|c|c|c|c}
\hline \multicolumn{10}{|c|}{$4=$} \\
\hline \\
\hline
\end{tabular}

* - مستوى الالالة

قيمة "ر " الجدولية عند مستوى 0.05 = 0.325

يتضح من جدول ( 5 ) وجود علاقة ارتباطيه دالة إحصائيا عند مستوى 0.05

بين التطبيقين لمحاور استمارة الاستبيان مما يدل على ارتفاع معامل ثبات الاستمارة.

وممـا سبق يكون استمارة الاستبيان بصـورته النهائيـة بعد إجراء المعـاملات

العلمية جاهز للتطبيق على عينـة البحث الأساسية حيث اشتملت عباراته على عدد

66عبـارة. ولزيـادة التأكد مـن الثبات تم إجـراء معامـل الثبات باسـتخدام أسـلوب ألفـا كرونباخ. والجدول التالى يوضح ذلك. 


\section{جدول ( 6 )}

\section{ثبات الاستبيان بتطبيق معامل ألفا كرونباخ ن= 40}

\begin{tabular}{|c|c|c|}
\hline \begin{tabular}{|c|} 
|ألفا كرونباخ \\
\end{tabular} & المحـاور & r \\
\hline *0.476 & الأهداف العامة لأكاديميات ومدارس كرة القدم & 1 \\
\hline$* 0.433$ & الخدمات التى تقدمها الأكاديميات للمشتركين & 2 \\
\hline$* 0.489$ & | إمكانات الأكاديمية المادية والبشرية & 3 \\
\hline$* 0.518$ & مصادر تمويل الأكاديمية & 4 \\
\hline$* 0.522$ & |الأساليب التسويقية & 5 \\
\hline \multirow{2}{*}{\multicolumn{3}{|c|}{ " }} \\
\hline & & \\
\hline \multicolumn{3}{|c|}{ 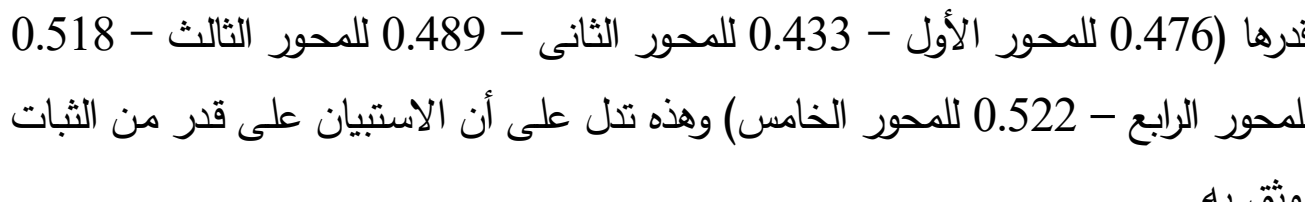 } \\
\hline
\end{tabular}

قام الباحث بتطبيق الدراسة الأساسية خلال الفترة من 22 / 2019/1 حتى 2019/2/21م علي عينة البحث الأساسية ومقدارها (180) فرداً وموزعة على النحو

- - رئيس وأعضاء مجلس إدارة مدارس وأكاديميات كرة القدم (5) أفراد. - الهيكل التظظيمي بأكاديميات ومدارس كرة القدم (119) فرداً. - - بعض أفراد الجمعيات العمومية (56) فرداً.

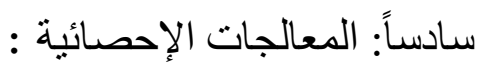


تم استخدام المعالجـات الإحصـائية المناسبة لطبيعـة البحث وذلك باستخدام برنامج الحزم الإحصائية (11.5) ل لإجراء العمليات الحسابية والإحصـائية للبحث:

- المتوسط الحسابي. - الانحراف المعيارى. - - -

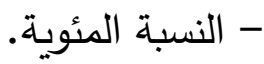

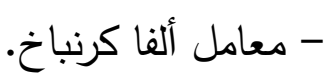
- معامل الارتباط البسيط.

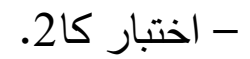
عرض ومناقشة النتائج أولاً: عرض النتائج: 


\section{جدول (7)}

التكرارات والنسبة المئوية وقيمة كا2 والوزن النسبي لأفراد عينة البحث لعبارات $180=$ ن

\begin{tabular}{|c|c|c|c|c|c|c|c|c|c|}
\hline \multirow{2}{*}{ الترتيب } & \multirow{2}{*}{ قيمة كا2 } & \multirow{2}{*}{ النسبى } & \multicolumn{2}{|c|}{ لا أوافق } & \multicolumn{2}{|c|}{ إلى حد ما } & \multicolumn{2}{|c|}{ موافق } & \multirow{2}{*}{ رقب } \\
\hline & & & نسبة.٪ & تكرار & نسبة\%٪ & تكرار & نسبة\% & تكرار & \\
\hline 6 & $* 24.133$ & 412 & 16.7 & 30 & 37.8 & 68 & 45.6 & 82 & 1 \\
\hline 12 & *160.633 & 392 & 2.8 & 5 & 76.7 & 138 & 20.6 & 37 & 2 \\
\hline 1 & *126.533 & 482 & 2.2 & 4 & 27.5 & 50 & 70.0 & 126 & 3 \\
\hline 9 & *54.233 & 409 & 9.4 & 17 & 53.9 & 97 & 36.7 & 66 & 4 \\
\hline 21 & $* 36.633$ & 313 & 38.9 & 70 & 48.3 & 87 & 12.8 & 23 & 5 \\
\hline 25 & *39.900 & 294 & 48.3 & 87 & 40.0 & 72 & 11.7 & 21 & 6 \\
\hline 16 & * 24.033 & 361 & 24.4 & 44 & 50.6 & 91 & 25.0 & 45 & 7 \\
\hline 4 & *32.433 & 415 & 13.3 & 24 & 42.8 & 77 & 43.9 & 79 & 8 \\
\hline 27 & *71.033 & 269 & 61.1 & 110 & 28.3 & 51 & 10.6 & 19 & 9 \\
\hline 22 & $* 40.033$ & 299 & 45.0 & 81 & 43.6 & 79 & 11.1 & 20 & 10 \\
\hline 11 & $* 22.800$ & 408 & 16.7 & 30 & 40.0 & 72 & 43.3 & 78 & 11 \\
\hline 13 & *143.433 & 388 & 5.0 & 9 & 74.4 & 134 & 20.6 & 37 & 12 \\
\hline
\end{tabular}

يتضـح مـن جدول (7) أن قيمـة كا2 المحسوبة لاستجابات عينـة البحث فى ارات

المحور الأول الأهداف العامـة لأكاديميـات ومـدارس كرة القدم جـاءت جميعها دالـة 
بائيا عن

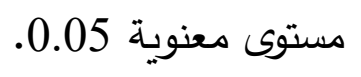

جدول ( 8 ( )

التكرارات والنسبة المئويـة وقيمة كا2 والوزن النسبي لأفراد عينة البحث لعبارات المحور التانى الخدمات التى تقدمها الأكاديميات للمشتركين

ن

\begin{tabular}{|c|c|c|c|c|c|c|c|c|c|}
\hline \multirow{2}{*}{ الترتيب } & \multirow{2}{*}{ قالمحسوبة كابة } & \multirow{2}{*}{ النسبى } & \multicolumn{2}{|c|}{ لا أوافق } & \multicolumn{2}{|c|}{ إلى حد ما } & \multicolumn{2}{|c|}{ موافق } & \multirow{2}{*}{ رقب } \\
\hline & & & نسبة\%٪ & تكرار & نسبة\% & تكرار & نسبة\% & تكرار & \\
\hline 6 & *30.633 & 413 & 13.9 & 25 & 42.8 & 77 & 43.3 & 78 & 1 \\
\hline 23 & *48.233 & 184 & 55.0 & 99 & 32.2 & 58 & 12.8 & 23 & 2 \\
\hline 22 & *14.933 & 320 & 42.2 & 76 & 37.8 & 68 & 20.0 & 36 & 3 \\
\hline 9 & $* 19.733$ & 400 & 17.8 & 32 & 42.2 & 76 & 40.0 & 72 & 4 \\
\hline 14 & $* 62.633$ & 356 & 20.6 & 37 & 61.1 & 110 & 18.3 & 33 & 5 \\
\hline 12 & 2.700 & 378 & 28.3 & 51 & 33.3 & 60 & 38.3 & 69 & 6 \\
\hline 4 & $* 40.033$ & 421 & 11.1 & 20 & 43.9 & 79 & 45.0 & 81 & 7 \\
\hline 17 & 4.133 & 352 & 32.2 & 58 & 40.0 & 72 & 27.8 & 50 & 8 \\
\hline 19 & *111.900 & 246 & 68.3 & 123 & 26.7 & 48 & 5.0 & 9 & 9 \\
\hline 21 & $* 68.700$ & 339 & 25.0 & 45 & 61.7 & 111 & 13.3 & 24 & 10 \\
\hline 2 & *52.933 & 430 & 7.8 & 14 & 45.6 & 82 & 46.7 & 84 & 11 \\
\hline
\end{tabular}

* مستوى *

قيمة كا2 الجدولية عند مستوى 0.05 =0.991

الدلالة

يتضـح مـن جدول (8) أن قيمـة كـا2 المحسوبة لاستجابات عينـة البحث فى

عبارات المحور الثانى الخدمات التى تقدمها الأكاديميات للمشتركين جاءت جميعها دالة إحصائيا عند مستوى معنوية 0.05، ماعدا العبارات أرقام (6، 8، 17، 18). 
جدول (9)

التكرارات والنسبة المئوية وقيمة كا2 والوزن النسبي لأفراد عينة البحث لعبارات

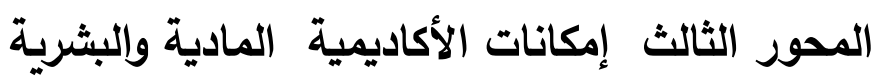

$180=$ ن

\begin{tabular}{|c|c|c|c|c|c|c|c|c|c|}
\hline \multirow{2}{*}{ الترتيب } & \multirow{2}{*}{ قالمسيوبة كام } & \multirow{2}{*}{ النسبى } & \multicolumn{2}{|c|}{ لا أوافق } & \multicolumn{2}{|c|}{ إلى حد ما } & \multicolumn{2}{|c|}{ موافق } & \multirow{2}{*}{ رقبارة } \\
\hline & & & نسبة\%" & تكرار & نسبة\% & تكرار & نسبة\%٪ & تكرار & \\
\hline 1 & $* 58.633$ & 443 & 8.3 & 15 & 37.2 & 67 & 54.4 & 98 & 1 \\
\hline 4 & $* 24.033$ & 406 & 16.1 & 29 & 42.2 & 76 & 41.7 & 75 & 2 \\
\hline 13 & ${ }^{*} 12.033$ & 323 & 42.2 & 76 & 36.1 & 65 & 21.7 & 39 & 3 \\
\hline 10 & 2.233 & 355 & 37.2 & 67 & 28.3 & 51 & 34.4 & 62 & 4 \\
\hline 7 & ${ }^{*} 61.433$ & 392 & 11.7 & 21 & 58.9 & 106 & 29.4 & 53 & 5 \\
\hline 11 & ${ }^{*} 8.633$ & 341 & 34.4 & 62 & 41.7 & 75 & 23.9 & 43 & 6 \\
\hline 9 & 2.233 & 365 & 29.4 & 53 & 38.3 & 69 & 32.2 & 58 & 7 \\
\hline 2 & $* 51.300$ & 432 & 8.3 & 15 & 43.3 & 78 & 48.3 & 87 & 8 \\
\hline 6 & * 48.233 & 401 & 11.7 & 21 & 53.9 & 97 & 34.4 & 62 & 9 \\
\hline
\end{tabular}

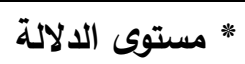

قيمة كا2 الجدولية عند مستوى $5.991=0.05$

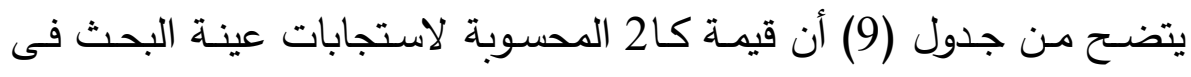

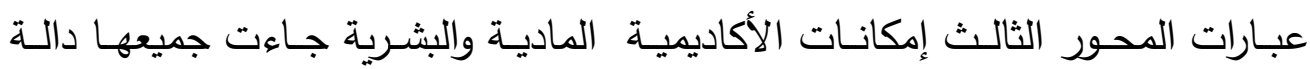
إحصائيا عند مستوى معنوية 0.05، ماعدا العبارات أرقام (4، 7، 12، 13). 


\section{جدول (10)}

التكرارات والنسبة المئويـة وقيمة كا2 والوزن النسبي لأفراد عينة البحث لعبارات المحور الرابع مصادر تمويل الأكاديمية

$180=ن$

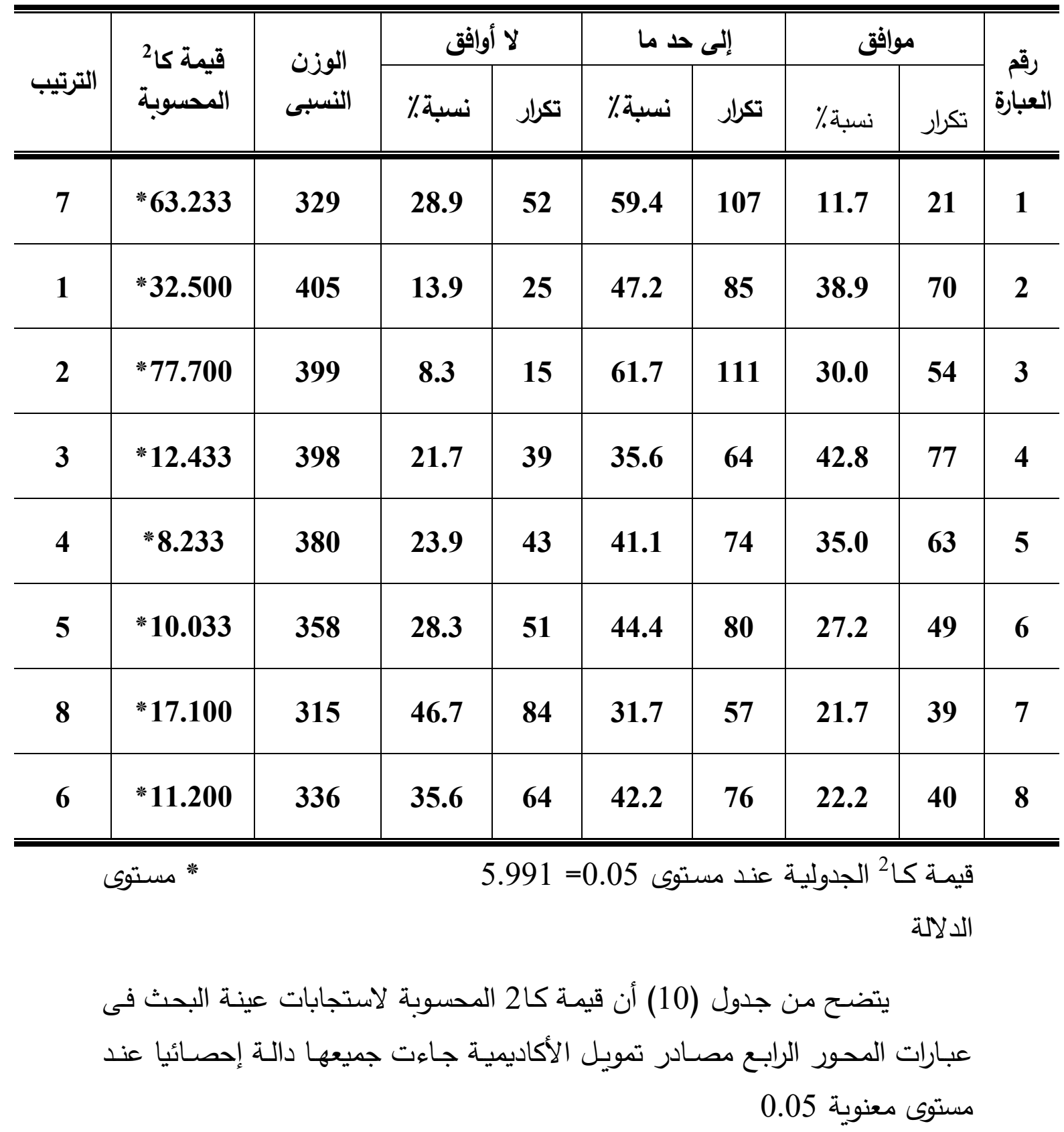




\section{جدول (11)}

التكرارات والنسبة المئوية وقيمة كا2 والوزن النسبي لأفراد عينة البحث لعبارات المحور الخامس الأساليب التسويقية

180 = ن

\begin{tabular}{|c|c|c|c|c|c|c|c|c|c|}
\hline \multirow[b]{2}{*}{ الترتيب } & \multirow{2}{*}{ قيمة كا2 المحسوبة } & \multirow{2}{*}{ الوزن النسبى } & \multicolumn{2}{|c|}{ لا أوافق } & \multicolumn{2}{|c|}{ إلى حد ما } & \multicolumn{2}{|c|}{ موافق } & \multirow{2}{*}{ رقم العبارة } \\
\hline & & & نسبةة| ن & تكرار & نسبة.| & تكرار & نسبة\% & تكرار & \\
\hline 16 & $* 19.200$ & 384 & 20.0 & 36 & 46.7 & 84 & 33.3 & 60 & 1 \\
\hline 17 & *44.033 & 382 & 16.1 & 29 & 55.6 & 100 & 28.3 & 51 & 2 \\
\hline 3 & * 48.133 & 434 & 10.0 & 18 & 38.9 & 70 & 51.1 & 92 & 3 \\
\hline 21 & * 50.833 & 355 & 22.2 & 40 & 58.3 & 105 & 19.4 & 35 & 4 \\
\hline 10 & $* 10.533$ & 394 & 22.2 & 40 & 36.7 & 66 & 41.1 & 74 & 5 \\
\hline 7 & *28.633 & 416 & 15.0 & 27 & 38.9 & 70 & 46.1 & 83 & 6 \\
\hline 18 & *38.100 & 369 & 23.3 & 42 & 55.0 & 99 & 21.7 & 39 & 7 \\
\hline 22 & * 8.400 & 354 & 30.0 & 54 & 43.3 & 78 & 26.7 & 48 & 8 \\
\hline 8 & $* 37.300$ & 411 & 12.2 & 22 & 47.2 & 85 & 40.6 & 73 & 9 \\
\hline 4 & *60.033 & 433 & 6.1 & 11 & 47.2 & 85 & 46.7 & 84 & 10 \\
\hline 12 & $* 40.300$ & 291 & 53.9 & 97 & 30.6 & 55 & 15.6 & 28 & 11 \\
\hline 20 & *9.033 & 359 & 28.3 & 51 & 43.9 & 79 & 27.8 & 50 & 12 \\
\hline 88 & $* 34.900$ & 411 & 12.8 & 23 & 46.1 & 83 & 41.1 & 74 & 13 \\
\hline 19 & $* 67.600$ & 360 & 18.9 & 34 & 62.2 & 112 & 18.9 & 34 & 14 \\
\hline 13 & $* 8.100$ & 387 & 23.3 & 42 & 38.3 & 69 & 38.3 & 69 & 15 \\
\hline 5 & *34.033 & 421 & 13.3 & 24 & 39.4 & 71 & 47.2 & 85 & 16 \\
\hline 13 & *27.100 & 387 & 17.8 & 32 & 49.4 & 89 & 32.8 & 59 & 17 \\
\hline 26 & $* 64.133$ & 274 & 54.4 & 98 & 38.9 & 70 & 6.7 & 12 & 18 \\
\hline 23 & * 15.233 & 329 & 37.2 & 67 & 42.8 & 77 & 20.0 & 36 & 19 \\
\hline 6 & * 47.233 & 419 & 9.4 & 17 & 48.3 & 87 & 42.2 & 76 & 20 \\
\hline 11 & *104.633 & 392 & 7.2 & 13 & 67.8 & 122 & 25.0 & 45 & 21 \\
\hline 1 & *78.233 & 455 & 10.0 & 18 & 27.2 & 49 & 62.8 & 113 & 22 \\
\hline 2 & $* 64.300$ & 447 & 7.2 & 13 & 37.2 & 67 & 55.6 & 100 & 23 \\
\hline 24 & $* 60.433$ & 313 & 35.0 & 63 & 56.1 & 101 & 8.9 & 16 & 24 \\
\hline 25 & $* 35.033$ & 296 & 52.8 & 95 & 30.0 & 54 & 17.2 & 31 & 25 \\
\hline
\end{tabular}

مستوى * مستو

قيمـة كـا2 الجدولية عند مستوى 0.05= 5.991

الدلالة 


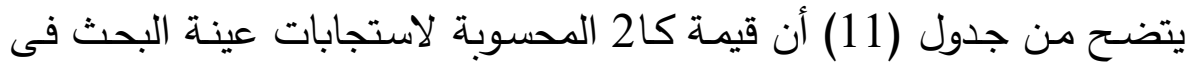
عبارات المحور الخامس الأساليب التسويقية جاءت جميعها دالة إحصائيا عند مستوى لأناته معنوية 0.05.

ثانياً : مناقثـــــة النتائهـ يتضـح من نتائج الجدول رقم (7) أن استجابات أفراد عينـة البحث لعبارات

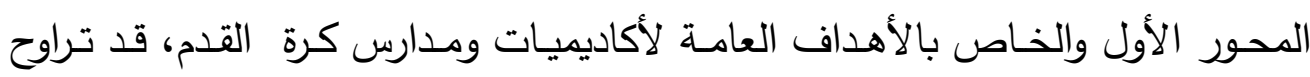

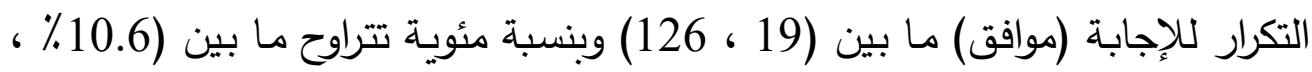
70.0\%), ويتراوح التكرار للإجابة (إلى حد مـا) مـا بين (50 ، 138) وبنسبة مئويـة

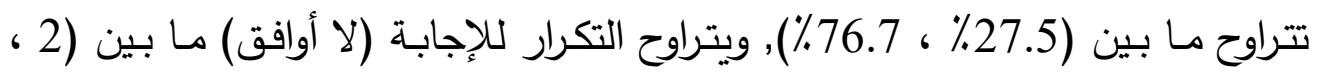

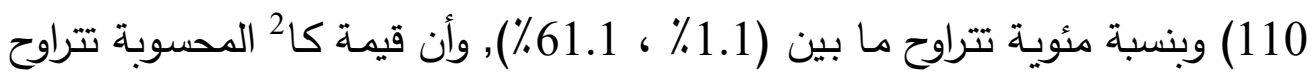

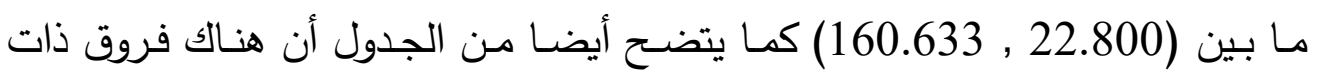

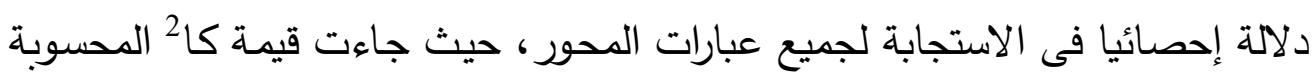
أكبر من قيمة كا2 الجدولية عند مستوى معنوية (0.05). ويرى الباحث أن استجابات أفراد عينة البحث على هذه العبارات تدل على أن

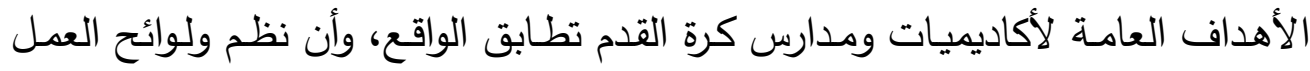
بهذه الأكاديميات تتصف بالمرونـة والتطور ، وأن هذه الأكاديميات تتفاعل مـع البيئة

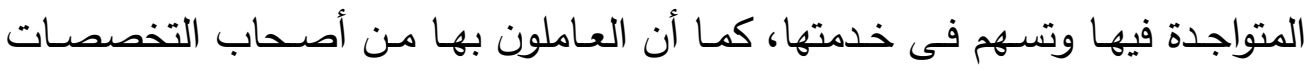
الملائمة لطبيعة نشاطها، ويفوض المديرون الصلاحيات للمختصين، بالإضـافة إلى أن الهيكل التنظيمى والذى يتضمن وظائف إدارية متخصصة فى مجالات مختلفة، بينما لا يوجد وصف وظيفى لمسئوليات كل وظليفة ، وأن واجبات ومسئوليات القائمين على ولى لئل

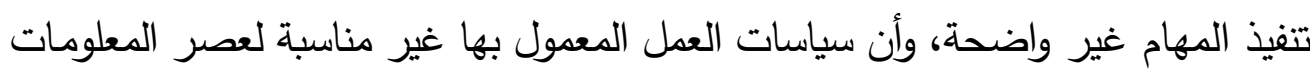
وثورة الاتصالات، كما لا يمنح الاداريين صلاحيات معاللة لحجم مسئولياتهم، كما لا يوجد وصف وظيفى لمسئوليات كل وظيفة. 
وفى هذا الصدد أشـار عـادل فاضل علي (2007م) أن التسويق فى المجال

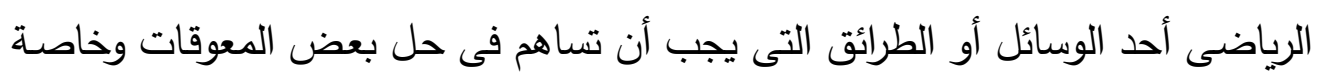

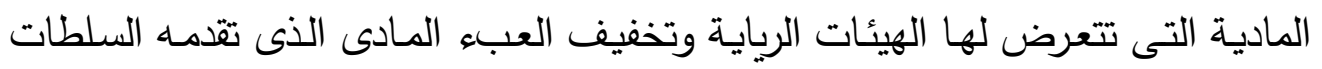

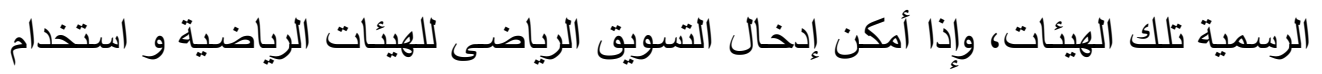

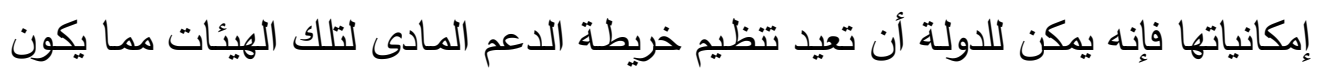

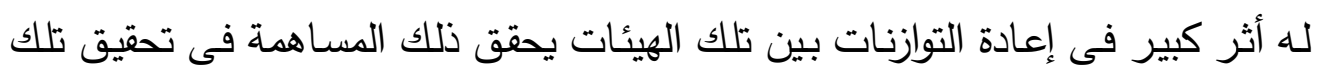
الكيئات لأهدافها المرجوة. (2: (2) يتضـح من نتائج الجدول رقم (9) أن استجابات أفراد عينة البحث لعبارات الدحور الثانى والخاص الخدمات التى تقدمها الأكاديميات للمشتركين قد تراوح التهات التكرار

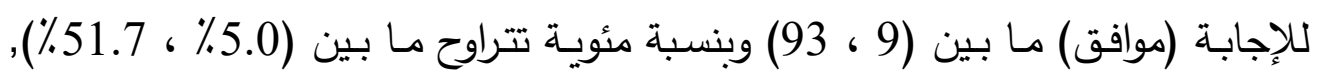

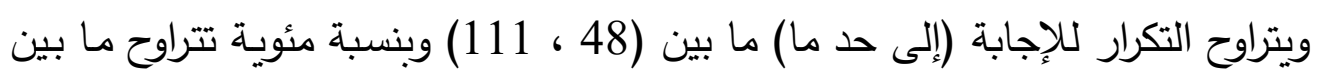

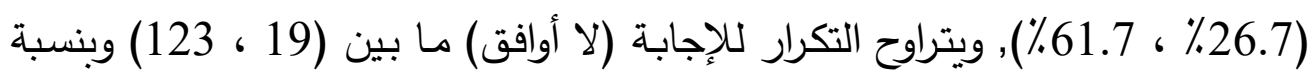

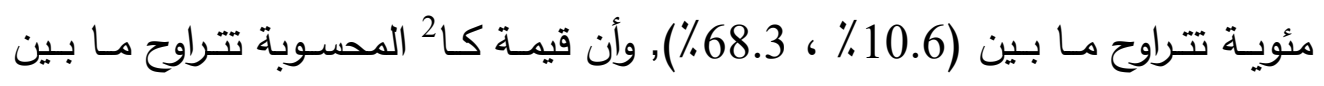

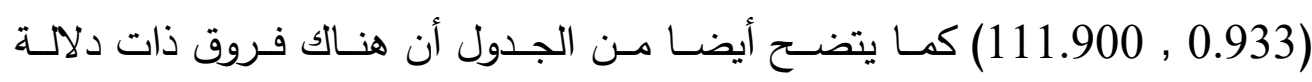

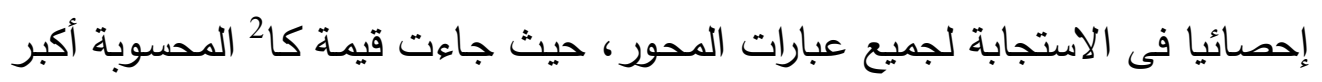
من قيمة كا² الجدولية عند مستوى معنوية (0.05).

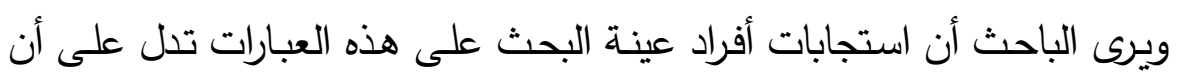

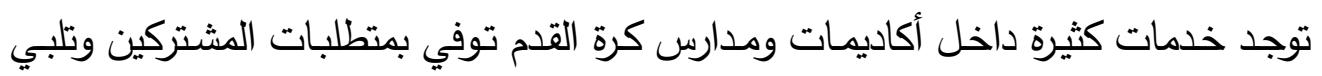

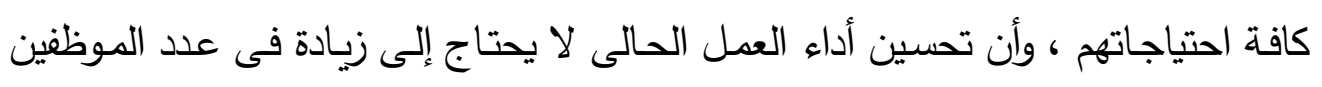

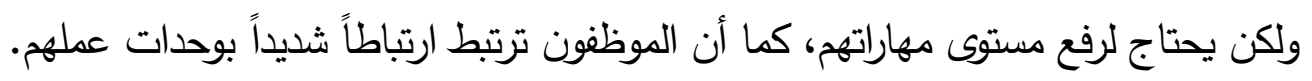

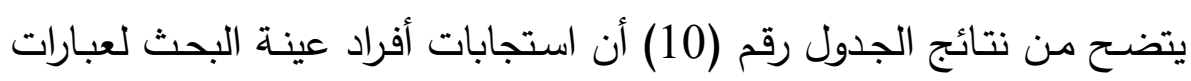

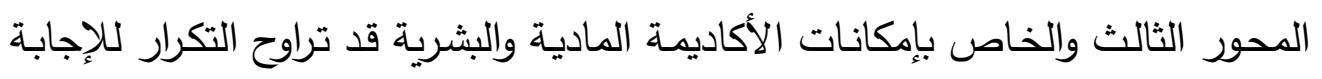

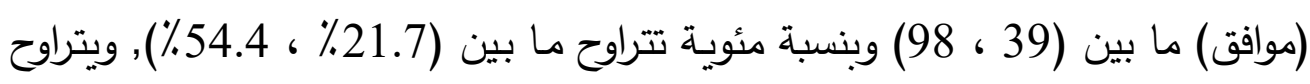

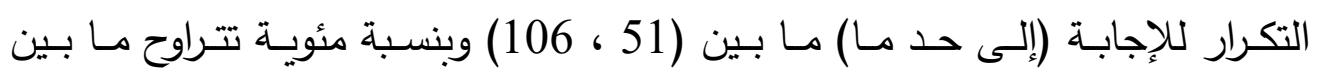

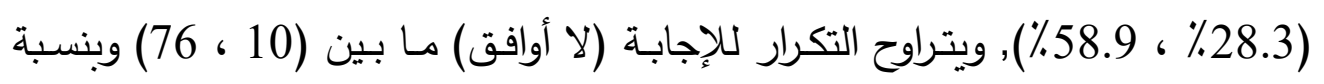




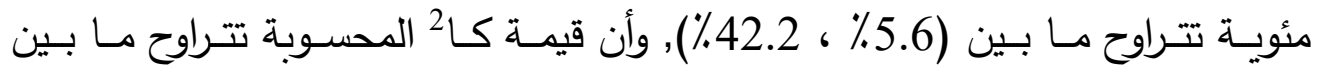

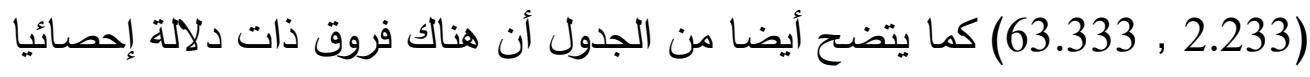

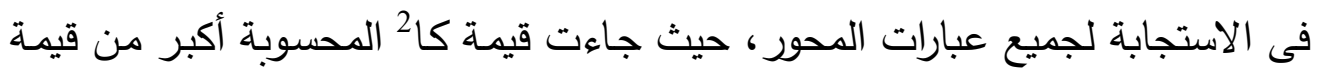
كا2 الجدولية عند مستوى معنوية (0.05). ويرى الباحث أن استجابات أفراد عينة البحث على هلى هذه العبارات تدل على أن

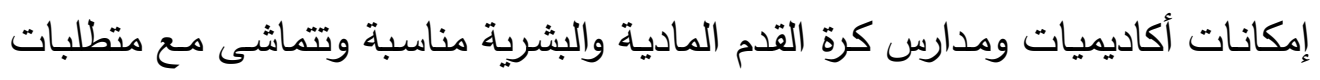

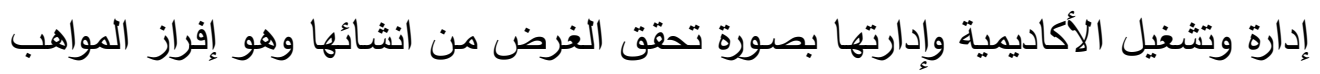

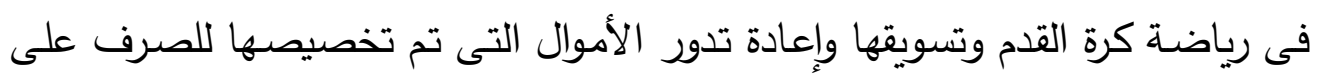

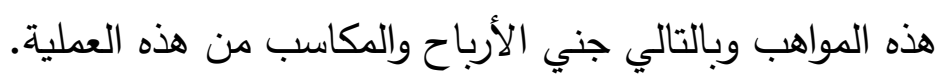

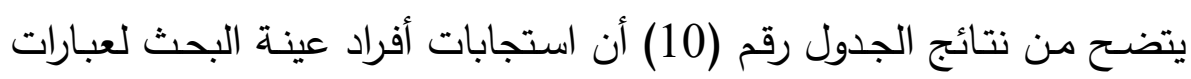

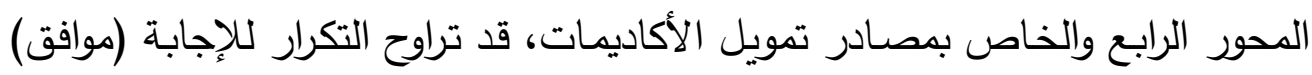

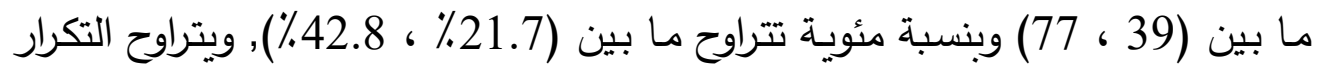

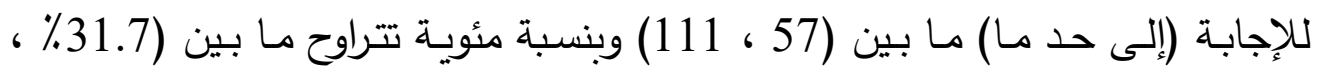

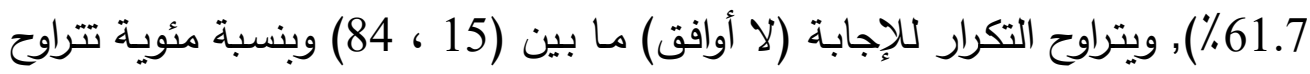

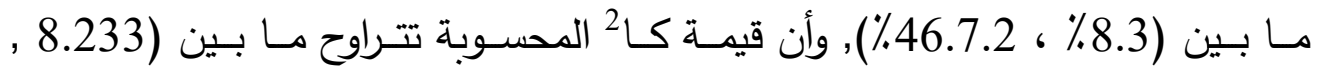

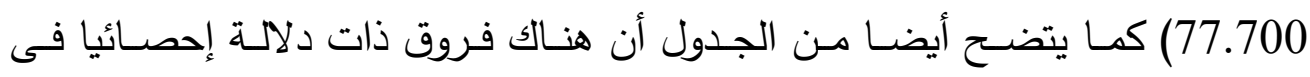

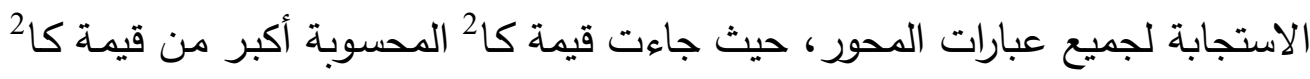
الجدولية عند مستوى معنوية (0.05).

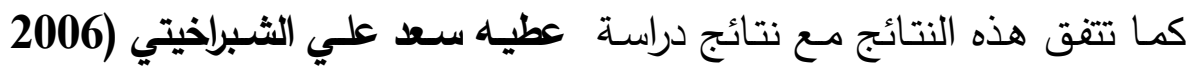

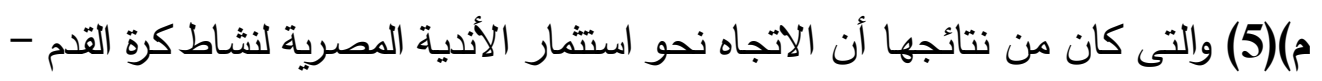

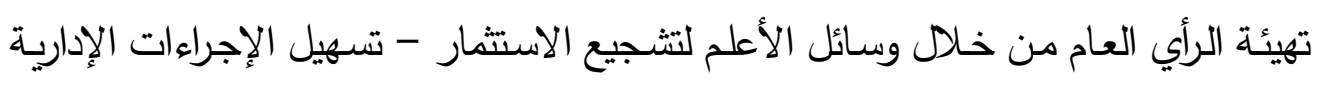

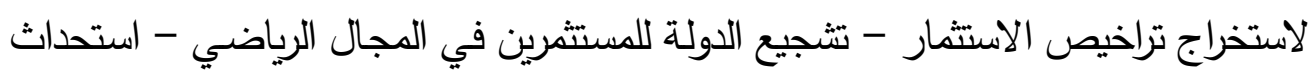

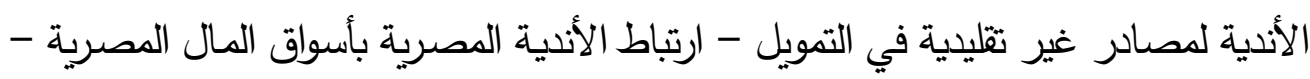

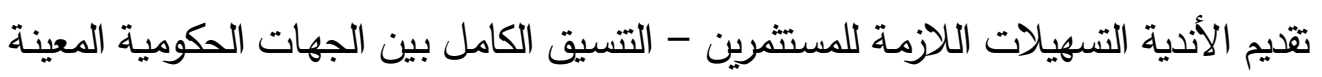

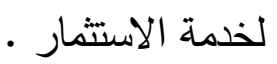


يتضح من نتائج الجدول رقم (12) أن استجابات أفراد عينة البحث لعبارات المحور

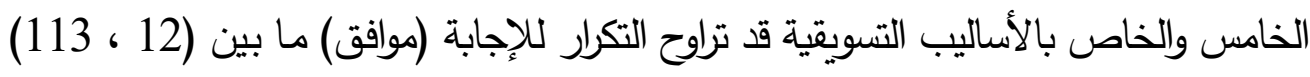

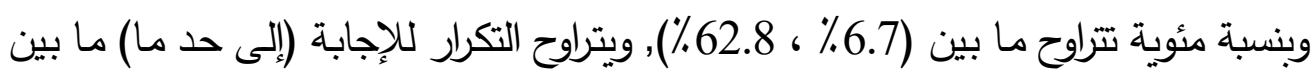

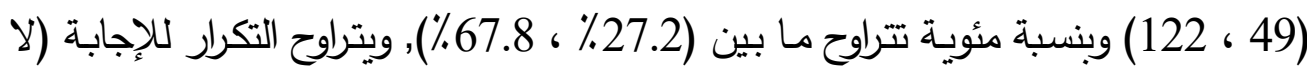

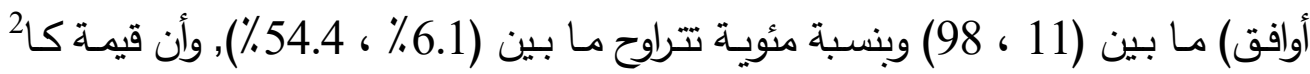

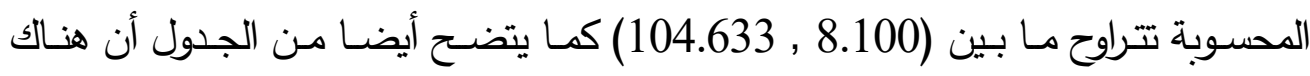

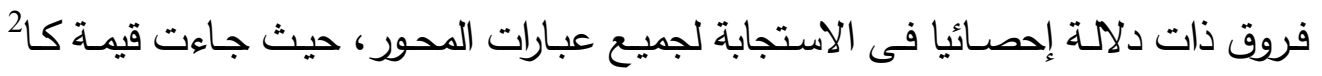
المحسوبة أكبر من قيمة كا² الجلولية عند مستوى معنوية (0.05).

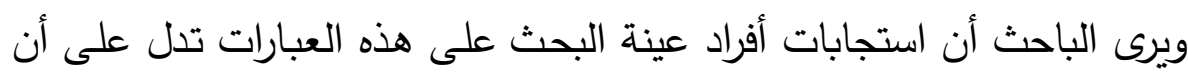

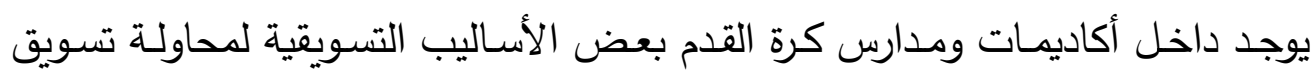
أكاديميهاتهم وبعض العناصر البارزة داخل هذه الأكاديميات واستثمارها الاستثمار

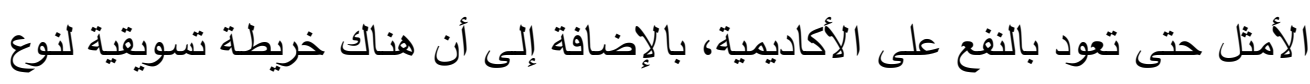

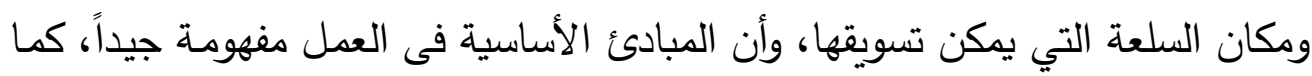

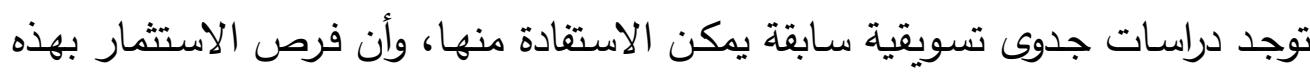

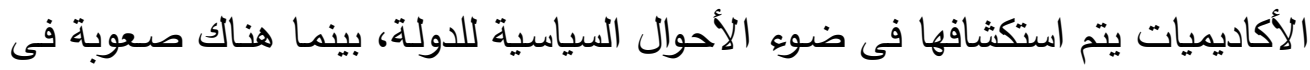

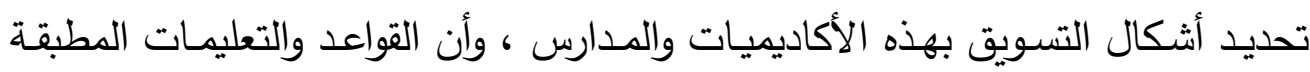

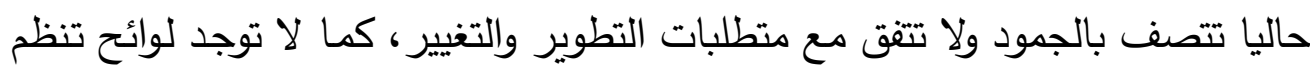

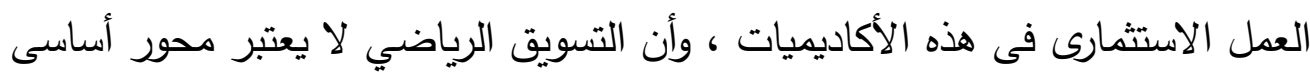

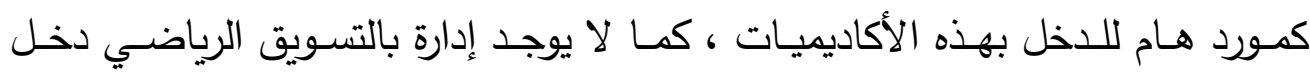

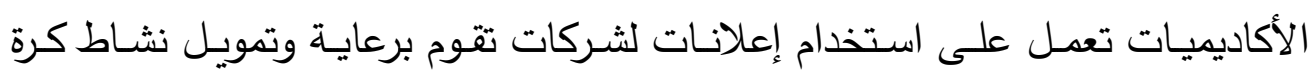
القدم. كما لا توجد ضـرورة لمعرفة الإمكانات البشرية والمادية قبل عملية التخطيط

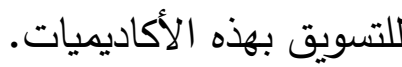

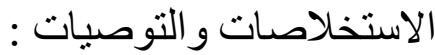

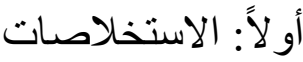


1- الاستخلاصـات الخاصـة بـالمحور الأول والخـاص بالأهداف العامسة لأكاديميـات

$$
\text { ومدارس كرة القدم }
$$

يوجـــ توجيـه بالاهتهـام بالكثـف عـن الموهـوبين فـى كـرة القـــم داخـل

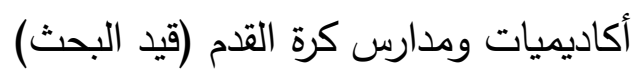

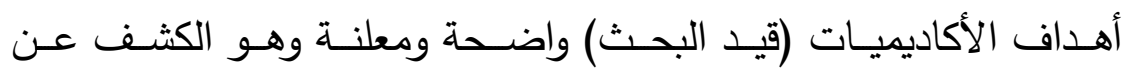
الموهوبين فى رياضة كرة القدم ورعايتهم وتأهيلهم وإعدادهم لعملية التسويق

$$
\text { والاحتراف. }
$$

كان من ضمن أهداف الأكاديميات ومدارس كرة القدم ما يلي : - تزويد الناشئين بالمهارات الفنية فى رياضة كرة القدم. - تتمية الوعي بأهمية احتراف رياضة كرة القدم. - توسيع قاعدة ممارسة رياضة كرة القدم.

2 - الاستخلاصــات الخاصـة بـالمحور الثـاني والخــاص بالخـــمات التــى تقـــمها الأكاديميات للمشتركين

•اهتمـت أكاديميـات ومـدارس كرة القدم (عينـة البحث) بإحضــار المـدربين المتخصصين لتدريب الناشئين وتزويدهم بمهارات كرة القدم. اهتمت الأكاديميات بضرورة توفير عقود تسويق واحتراف للاعبين. راعت الأكاديميات وضع الميزانيات المخصصة للتسويق.

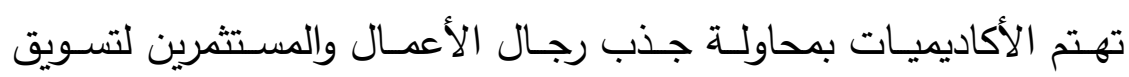

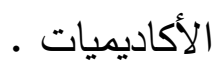
تهتم الأكاديميات بعمل المباريات والرحلات التدريبية. 3 - الاستخلاصـات الخاصـة بالمحور الثالث والخاص بإمكانات الأكاديمية الماديـة والبشرية.

يتناسب عدد الناشئين بالفرق المختلفة مـع سياسـات التطوير والاستثمار داخل بعض الأكاديميات ومدارس كرة القدم. 
عدد المدربين والمتخصصين الموجودين داخل بعض الأكاديمات يتناسب مع سياسة التسويق بالأكاديميات. تتناسب الملاعب والأدوات الموجودة ببعض الأكاديميات ومدارس كرة القدم مع السياسة التسويقية لجذب الاستثمارات. يتتاسب موقع بعض الأكاديميـات مـع سياسـة التسـويق داخل أكاديميـات ومدارس كرة القدم لجذب المستثمرين للاستثمار فيها. 4 - الاستخلاصات الخاصة بالمحور الرابع والخاص بمصادر تمويل الأكاديمية تقوم بعض الأكاديميات بتوفير الموارد المالية لدعم نشاط كرة القدم بها.

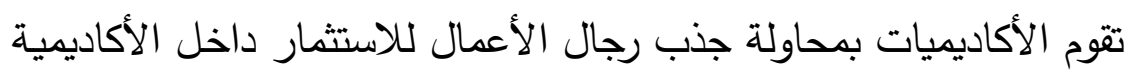
وتسويق الخدما داخلها. الموارد الحالية ضـعيفة وتؤثر على استقطاب المدربين المتخصصين فى

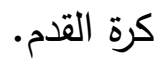
الموارد المالية الحالية لا تكفي بمتطلبات وأهداف الأكاديميات. 5 - الاستخلاصات الخاصة بالمحور الخامس والخاص بالأساليب التسويقية توجد خطط واضحة للتسويق داخل بعض الأكاديميات ومدارس كرة القدم داخل دولة الكويت. وضوح الأهداف التسويقية لبعض أكاديميات ومدارس كرة القدم.

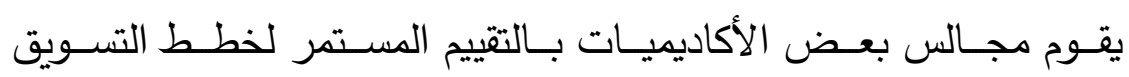
بالأكاديميات.

تقوم بعض الأكاديميات بالإعلان عن تسويق اللاعبين بصورة مناسبة.

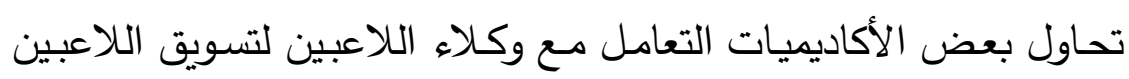
الموهوبين بها. تحاول بعض الأكاديميات لجذب نجوم كرة القدم لتفعيل عملية التسويق

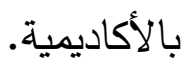


تستخدم بعض الأكاديميـات بتجـارب الأنديـة الكبيرة فى عمليـة التسويق بالأاديمية. تقوم بعض الأكاديميات بالمشـاركة بالفرق الختلفة فى البطولات المختلفة بغية الوصول إلى تسويق جيد لأكادميتها.

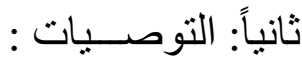
فى ضوء نتائج البحث والاستخلاصسات التى تم التوصل إليها يوصس الباحث بما يلى: - - ضرورة أن يكون الهدف الأساسي لإقامسة الأكاديميات ومدارس كرة القدم هو التسـويق الجيـد للمواهـب فـى رياضـة كـرة القـدم والــى يسـاعد على انتشـار الأكاديمية بين الأكاديميات الأخرى. - - - ضـرورة توفير كاف الخدمات التى من شأنها أن تجذب المستثمرين وتسويق الخدمات للمشتركين والناشئين. - - ضـرورة توفير المخصصـات المالية بالأكاديميات ومدارس كرة القدم للصرف على المدربين والأجهزة والأدوات والملاعب. - - ضــرورة اسـتقطاب المــدبين المتخصصــين والمـؤهلين للتعامـل مـع البـراعم والناشئين فى رياضة كرة القدم. - - ضرورة توفير المناخ الجيد والموارد لعملية التمويل وهذا لا يتم إلا بتسويق كافة حلة موارد الأكاديميات من (ملاعب - أدوات - خدمات) لجذب المستثمرين لعملية الاستثمار داخل الأكاديميات. - - ضرورة استخدام استراتيجية التسويق المقترحة لتسويق أكاديميات ومدارس كرة القدم بلدولة الكويت. - - الاستفادة من بعض المشاهير ونجوم كرة القدم فى تسويق أكاديميات ومدارس كرة القدم بدولة الكويت. - - استضـافة بعض المناسبات والـدورات الخاصـة بالمدربين والحكـام والإداريـين داخل الأكاديميات للمساهمة فى عملية التسويق للأكاديمية. 
- الاهتمام بإعطاء الحقوق التسويقية لبعض شعارات الدورات التدريبية جمباً إلى جنب مع شعار أكاديميات ومدارس كرة القدم. 


$$
\text { المر اجـع }
$$

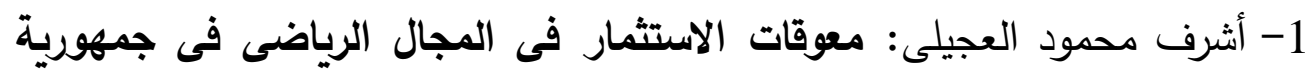

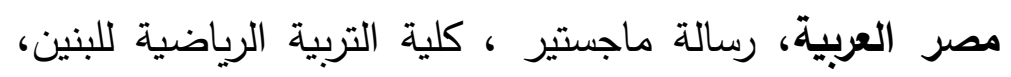

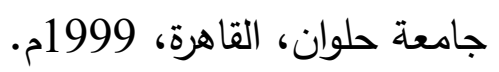

2- حامد عبد المجيد دراز : السياسة المالية ، مركز الإسكندرية للكتاب ، 2000م . 3- حسن أحمد الثافعى: إدارة الجودة الثاملة فى التربية البدنية والرياضية، دار

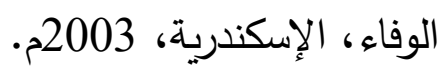

4- عادل فاضل علي : التسويق فى المجال الرياضى، كلية التربية الرياضية، جامعة

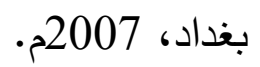

5- عطية سعد سعد على الثبراخيتى: " استثمار الأندية المصرية لنشاط كرة القدم

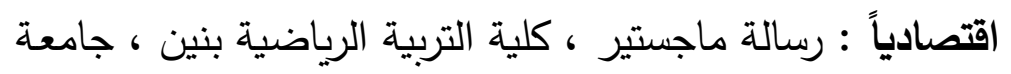

$$
\text { الزقازيق ، 2006م. }
$$

6- كمال الدين عبد الرحمن دروي، محمد صبحى حسانين: موسوعة متجهات إدارة

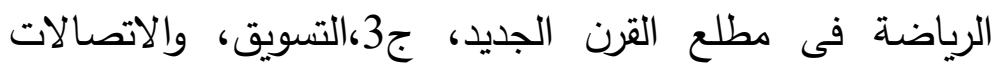

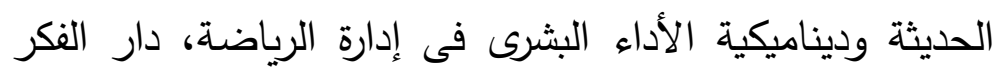

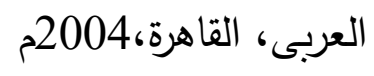

7- محدد عبد الله عبد الرحيم: التسـويق المعاصـر، كلية التجارة، جامعـة القاهرة،

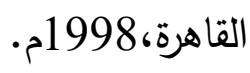

8- محمد محمود إبراهيم مندور : دراسة تقويمية لإدارة مجمع الصالات الرياضية بهيئة ستاد القاهرة من وجهة النظر الرياضية والاقتصادية،

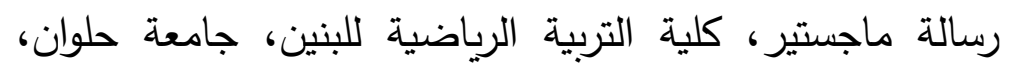

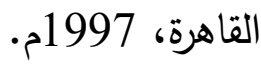


9- وليد أحمد سامي: " تقويم أسـاليب تسويق أنثطة الترويج الرياضسي فى بعض التربس

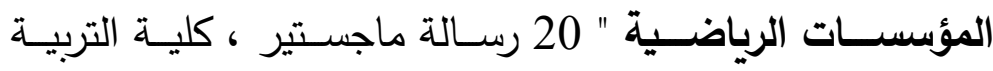

$$
\text { الرياضية بنين · جامعة حلوان ، 2000م. }
$$

10- John. R. Johnson: Marketing and Sonsarship, L.A., 1996.

11- Kelin: Whats is sport marketing smlsrla Dos-sport marketing 1995

12- Kolter, P., \& Armostrong, g.: Principles of Marketing, Prentice Hall, Int., 2001 